\section{Structural Organization of the Trans- cription of Ribosomal DNA in Oocytes of the House Cricket}

THE DNA molecules which contain the cistrons for ribosomal RNA (rDNA) consist of repeats of alternating segments of (i) regions which are transcribed into the primary rRNA precursors (pre-rRNA) and (ii) regions which are either not transcribed (corresponding to "spacers" sensu Miller and Beatty ${ }^{1}$ ) or might be, perhaps in parts, transcribed into RNA molecules which, however, are not covalently linked with pre-rRNA ("spacers" sensu Reeder and Brown" ; for demonstration of partial transcripts from spacers see Scheer et al. ${ }^{3}$ ). The relative arrangement of the "spacer" units and the stretches coding for pre-rRNA (corresponding to the matrix units of Miller and Beatty $\left.{ }^{1,4}\right)$ has been elucidated by different methods in chromosomal and extrachromosomal rDNA of diverse amphibian species, including urodeles and anuran $s^{1,3-13}$. In the clawed toads, Xenopus laevis and X. muelleri, according to differential DNA denaturation studies ${ }^{12,13}$, this pattern of arrangement is identical in both chromosomal ("nucleolus organizer") and extrachromosomal ("amplified") rDNA. Extrachromosomal nucleolar material consisting of the actively transcribing amplified rDNA is especially suitable for biochemical and electron microscopic studies because it provides a natural enrichment of this kind of DNA in a state which is topologically isolated from all the other chromatin. We have therefore chosen, in order to examine the generality of the organization of transcribing rDNA, another amplified rDNA system, the extrachromosomal DNA masses which occur in the oocytes of diverse insects and constitute a considerable amount of the total nuclear DNA (for example, $59 \%$ in Tipula oleracea ${ }^{14}, 23-35 \%$ in Dytiscid beetles $^{15}$, and $14-31 \%$ in Acheta domesticus $\left.{ }^{16-19}\right)$. As has been shown by numerous authors ${ }^{18,20-24}$ a favourable material in this respect is the house cricket, $A$. domesticus.

Using a modified "Miller technique" we have spread the isolated nuclei of $A$. domesticus diplotene oocytes, that is, oocytes at a stage in which the amplified rDNA is actively transcribing and is highly dispersed over most of the nuclear interior $^{20-26}$.

Figure 1 shows an electron micrograph of a part of such transcriptionally active deoxyribonucleoproteins (DNP) containing the rRNA cistrons. When partially spread, the DNP and their associated RNP are clumped together in aggregates (Fig. 1a, top), the structure of which is revealed on further spreading (Fig. 1a, bottom). Regions on the long DNP axes covered in lateral fibrils of gradually increasing lengths, presumed to represent the protein-complexed growing prerRNAs (matrix units sensu refs 1 and 4), are interspersed with "naked" (that is matrix free) regions (the "spacers" in the definition of ref. 1). The whole arrangement suggests a periodic pattern (Figs $1 b$ and 2) similar to that which has been described for the nucleoli in amphibian oocytes ${ }^{1,3-10}$. We noticed in Acheta oocyte nucleolar spreads a much more pronounced tendency towards lateral sticking together of the RNP fibrils than we observed in the extrachromosomal nucleoli of amphibian oocytes ${ }^{3}$. This often resulted in a "snail-shell" like formation within the matrix unit (Fig. 2). The distance between the RNP fibril bases, that is the repeat distance of the RNA polymerase molecules ${ }^{1,4}$, was as small as about $250 \AA$ (centre-to-centre) indicating an almost maximal packaging of the working RNA polymerases. We consistently observed that terminal knobs on the lateral RNP fibrils are detected only in the second half of each matrix unit (Fig. 1). A similar absence of terminal knobs in the lateral fibrils of the anterior (start) part can be detected in the pre-rRNA cistrons of HeLa cells (Figs 7 and 8 in ref. 8) and amphibian oocytes ${ }^{3-5,7-10}$.
We have measured in various preparations the length of the matrix units, the matrix-free regions, the whole repeating unit $^{3}$, and the intramatrical stretch of DNP in which the lateral fibrils do not show the terminal knobs. The data are summarized in Fig. 3. The average matrix unit length was $5.58 \pm 0.8$ (s.d.) $\mu \mathrm{m}$, but could in individual matrix units show an extreme length of up to $7.6 \mu \mathrm{m}$. Likewise, the spacer segments and the corresponding total repeat units were very long with means of $5.49 \pm 1.0 \mu \mathrm{m}$ and $11.07 \pm 1.0 \mu \mathrm{m}$, respectively. The regions in the first part of the matrices in which the RNP fibrils had no terminal knobs were fairly constant around an average of $2.53 \pm 0.35 \mu \mathrm{m}$. We only occasionally identified lateral fibres attached to the intermatrical ("spacer") regions (Fig. 2) which we have previously described in amphibian oocytes.

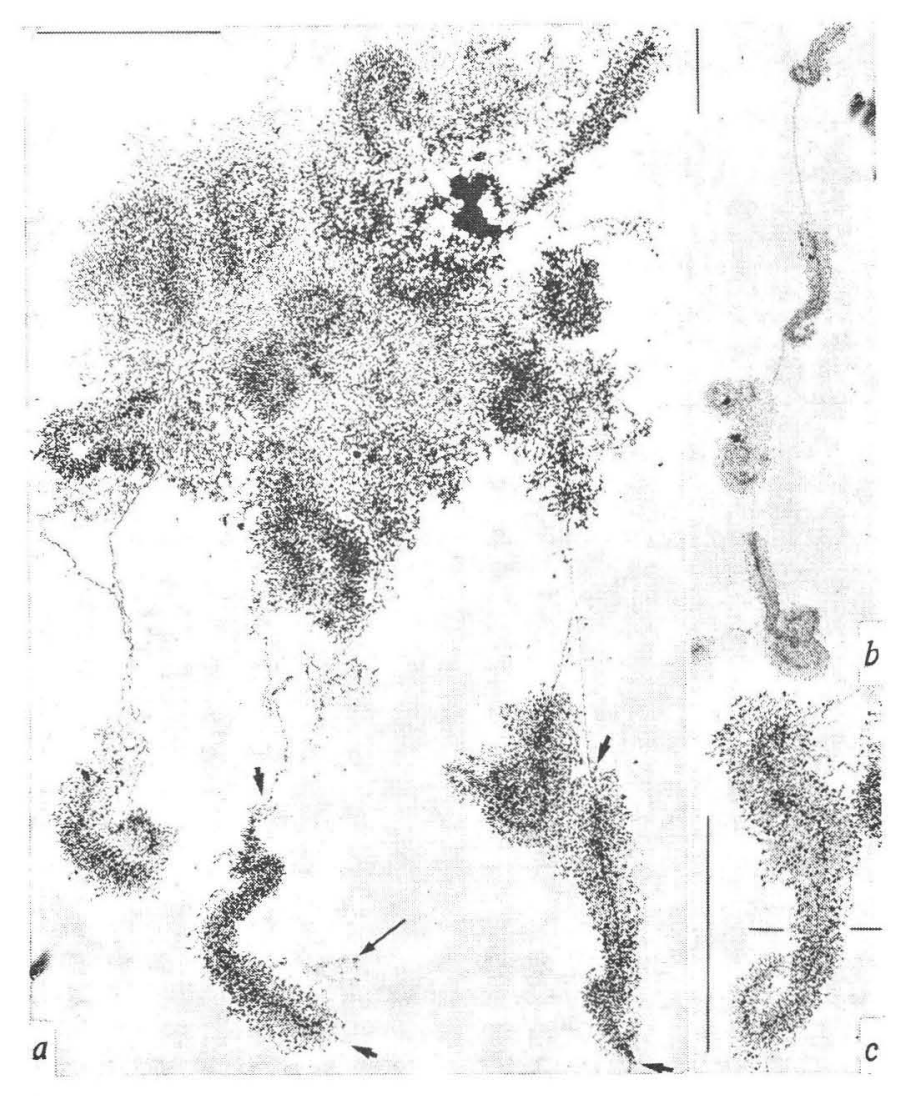

Fig. $1 a$, Electron micrograph of a moderately spread positively stained preparation of Acheta oocyte extrachromosomal nucleolar material showing transcriptionally active DNP containing the rRNA cistrons. For each spread preparation four to six nuclei (diameter $90-100 \mu \mathrm{m}$ ) from diplotene stage oocytes of Acheta domesticus (insects kept at $26^{\circ} \mathrm{C}$ ) were manually isolated in $0.1 \mathrm{M} \mathrm{NaCl}-\mathrm{KCl}(1: 5)$ medium, washed twice and transferred into a small drop of distilled water adjusted with borate buffer to $p \mathrm{H} 9$ (refs. 3 and 8 ). The nuclei were again washed twice until all adherent cytoplasmic débris was removed. The nuclear envelopes were then removed with watchmaker's forceps. The nuclear contents were dispersed and allowed to spread for about $10 \mathrm{~min}$ at about $18^{\circ} \mathrm{C}$ and were processed further according to the procedures described ${ }^{3,8}$. Along the DNP strands one sees alternating regions of fibril covered (matrix) and free ("spacer") intercepts. The dense aggregate in the upper right might represent clumped (perhaps inactive) DNP. Arrowheads denote starts and termini of individual matrix units. The long arrow in the bottom part points to an extended lateral RNP fibril. Scale $=3 \mu \mathrm{m}$ in all figures. $b$, In more spread nucleoli the periodical sequence of "spacer" and matrix units is clearly seen. Note the tendency of the matrix material to aggregate into coil formations. Matrix units exhibit gradients in the lengths of their lateral fibrils. The terminal knobs of the lateral fibrils are confined to the posterior halves of the matrix units ( $c$, above the line indicated by the horizontal bars). 
A fully extended single-strand RNA transcript should attain approximately $75 \%$ of the length of its double stranded DNA template (assuming the B-form ${ }^{27-30}$ ). It is noteworthy that the lengths of the RNP fibrils are much below a value of 0.75 times of the distances of their insertion points from the matrix unit start. This discrepancy is more pronounced in the fibrils in the posterior part of the matrices. This has also been observed to a lesser content in the amphibian oocyte nucleoli ${ }^{3,5,7}$; it is, however, much more eye-catching in the cricket oocyte, perhaps simply as a consequence of

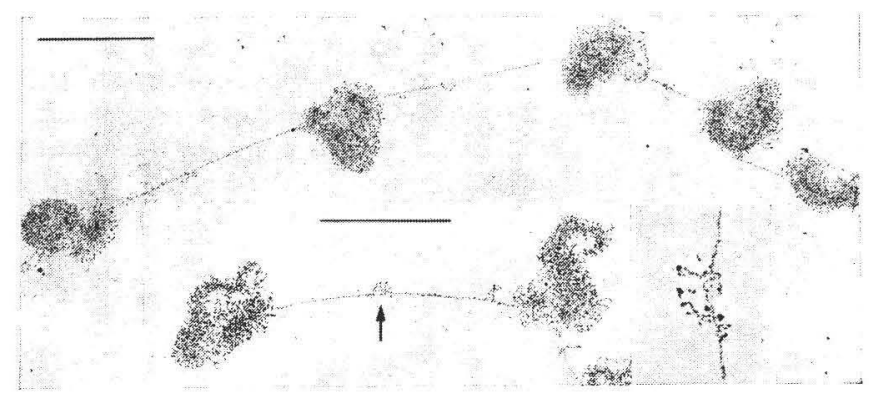

Fig. 2 A typical sequence of repeating units showing extended "spacer" regions alternating with coiled matrix units. Occasionally, one observes small groups of fibrils within the "spacers" (for example at the arrow in the left insert; details resolved at higher magnification are shown in the right insert at $\times 16,000$ ), resembling the "spacer" transcripts described in amphibian oocyte nucleoli ${ }^{3}$.

the longer matrix units. A good deal of this discrepancy might be due to the terminal coiling of the longer RNP fibrils ${ }^{8}$. In addition, however, the present micrographs indicate that even in the RNP fibrils in the beginning of a matrix unit there must be some coiling of the RNA, since at the start or the terminal part of a matrix unit (Fig. 1a) there is sometimes an unravelling of individual fibrils. These findings, as well as the observation that in the second half of matrix units the successive fibrils do not significantly increase in length, suggest that conformational changes of the growing RNP influence the measured fibrillar lengths to a high degree.

We have also determined the molecular weights of the mature rRNAs and their precursors by injecting tritiated uridine into the body cavity of females and analysing whole ovaries after various time intervals. The large (28S) rRNA of Acheta ovaries shows the same electrophoretic mobility in acrylamide gels as the corresponding rRNA from $X$. laevis (Fig. 4). The small (18S) rRNA of Acheta, however, migrates more slowly than the small rRNA of Xenopus (Fig. 4). Taking molecular weights of 1.52 and $0.7 \times 10^{6}$ for the $X$. laevis marker rRNAs $s^{31,32}$ molecular weights of 1.52 and $0.72-0.74 \times 10^{6}$ have been calculated for the mature rRNAs of Acheta ovaries. Comparable values have been reported for somatic tissues of other insect species ${ }^{32-36}$. The predominant precursor (pre-rRNA) peak appears with a mean molecular weight of $2.8 \times 10^{6}$ and intermediate processing products were identified at positions corresponding to molecular weights of about 1.7 and $1.1 \times 10^{6}$ (Fig. 4). In other insects the molecular weight of the pre-rRNA has been determined by gel electrophoresis to be 2.6 (Chironomus tentans $^{35}$ ), 2.85 (Drosophila virilis and D. melanogaster ${ }^{33}$ ), 3.3 (Chironomus tentans ${ }^{34}$ ), and $3.8 \times 10^{6}$ (Aedes aegypt ${ }^{36}$ ). Minor components of molecular weights higher than 3.0 $\times 10^{6}$ were also identified. In parallel, we analysed the RNA on $1 \%$ 'Agarose' gels and here we consistently found, besides the main precursor peak, some DNase-resistant radioactivity in regions corresponding to molecular weights of up to $6.5 \times 10^{6}$. We have, however, so far not been able to show definitely that this heavy RNA ranging from about 3 to $6.5 \times 10^{6}$ is $\mathrm{rRNA}$ precursor material.

How do our measurements relate to the rRNA hybridization experiments performed with Acheta rDNA by Limade-Faria and coworkers ${ }^{18,37}$ ? These authors noted that the



Fig. 3 Diagram of the distribution of the lengths of matrix units (dotted blocks in $a$ ), "spacer" regions $(b)$, and of the intramatrix stretches in which the lateral fibrils do not bear terminal dense knobs (hatched blocks in $a$ ). Only sufficiently stretched axes with well identified regions have been considered in these measurements.

Acheta rDNA hybridizes only with a very low efficiency, indicating that only about $7.5 \%$ of the satellite DNA (double strand) consists of sequences homologous to those of the mature rRNAs ${ }^{37}$. From our data we can estimate that DNA homologous to mature rRNA (that is, to a total molecular weight of $1.52+0.72 \times 10^{6}=2.24 \times 10^{6}$, corresponding to $2.33 \mu \mathrm{m}$ rDNA) comprises about $21 \%$ of the repeating unit.

The arrangement of matrix units and "spacer" segments on the rDNA axes of amplified rDNA of the house cricket resembles the pattern described in amphibia in various aspects: (i) The lateral fibrils increase in length within each transcribing unit and have, in the posterior part of the matrix unit, terminal knobs at their free ends. (ii) The serial density of lateral fibrils on the DNP axes, that is the packaging of the rRNA polymerases, is almost identical. (iii) The ratio of "spacer" length to matrix length is about $1: 1$ (for other biological material see Table 1). On the other hand, there are some marked differences to the situation in amphibia. Both spacer and matrix units are much longer, the mean values are about twice the corresponding values of the amphibia. Correspondingly, the total repeat unit is also much longer $(11.1 \mu \mathrm{m}$ compared with $5.1 \mu \mathrm{m}$, see Table 1). It is not clear whether these longer matrix units reflect the existence of longer rRNA precursors (of up to $5.5 \times 10^{6}$ daltons) in such insect material, compared with the values reported in amphibia (see, however, Caston and Jones ${ }^{38}$ ). Other than in the amphibian oocyte nucleoli we have so far been unable to establish a correspondence of pre-rRNA length to the mean matrix unit length. This might indicate that the primary transcript (provided that it is a full and covalent transcript) is a longer molecule but is rapidly processed to the first stable intermediate product which then might be represented by the $2.8 \times 10^{6}$ dalton peak. Such conjectures of possible very long pre-rRNA find some support in reports from amphibia ${ }^{3,38}$, in mammalian cells ${ }^{39}$ and also in results of studies of in vitro RNA synthesis of isolated rat liver nucleoli ${ }^{40}$. As an alternative it is interesting to note that a full transcript of the Acheta matrix unit would be long enough to include two molecules each with the length 
Table 1 Structural Data of Arrangement of rRNA Cistrons in Nucleolar DNA

\begin{tabular}{|c|c|c|c|c|c|c|c|c|}
\hline Object & $\begin{array}{l}\text { Topological } \\
\text { state }\end{array}$ & Method & $\begin{array}{l}\text { Refer- } \\
\text { ence }\end{array}$ & $\begin{array}{c}\text { Matrix } \\
\text { unit } \\
\text { length } \\
(\mu \mathrm{m})\end{array}$ & $\begin{array}{l}\text { Spacer } \\
\text { unit } \\
\text { length } \\
(\mu \mathrm{m})\end{array}$ & $\begin{array}{l}\text { Repeat } \\
\text { unit } \\
\text { length } \\
(\mu \mathrm{m})\end{array}$ & $\begin{array}{l}\text { Ratio } \\
\text { “spacer”: } \\
\text { "matrix } \\
\text { unit” }\end{array}$ & $\begin{array}{l}\% \text { Nucleolar } \\
\text { DNA (double } \\
\text { strand) homo- } \\
\text { logous to rRNA }\end{array}$ \\
\hline Chironomus thummi & Chromosomal & Spreading technique & 41 & 2.2 & 0.45 & 2.65 & 0.20 & 87 \\
\hline Acheta domesticus & Extrachromosomal & Spreading technique & $\begin{array}{l}\text { This } \\
\text { study }\end{array}$ & 5.58 & 5.49 & 11.07 & 0.98 & 21 \\
\hline Triturus viridescens & Extrachromosomal & Spreading technique & $1,4-9$ & $2.2-2.5$ & $0.73-0.83 *$ & $2.9-3.3 \dagger$ & $\sim 0.33$ & $71 \div$ \\
\hline$T$. alpestris & Extrachromosomal & Spreading technique & 3 & 2.9 & 2.2 & 5.1 & 0.76 & $43^{+}$ \\
\hline$T$. cristatus & Extrachromosomal & Spreading technique & 3 & 2.4 & 2.2 & 4.6 & 0.92 & 48 \\
\hline$T$. helveticus & Extrachromosomal & Spreading technique & 3 & 2.6 & 2.2 & 4.8 & 0.85 & 46 \\
\hline Xenopus laevis & Extrachromosomal & Spreading technique & 1 & $2.0-2.5$ & $0.67-0.83 *$ & $2.7-3.3$ & $\sim 0.33$ & 77 \\
\hline$X$. laevis & Extrachromosomal & Spreading technique & 3 & 2.6 & 2.1 & 4.7 & 0.81 & 49 \\
\hline$X$. laevis & Extrachromosomal ${ }^{\mathrm{xx}}$ & $\begin{array}{c}\text { Denaturation mapping } \\
\text { of isolated rDNA }\end{array}$ & 12 & 3.1 & 2.3 & 5.4 & 0.74 & 43 \\
\hline$X$. muelleri & Extrachromosomalxx & Denaturation mapping & 13 & 3.1 & 1.9 & 5.0 & 0.61 & 46 \\
\hline Rat liver & Chromosomal & Spreading technique & $\S$ & 5.2 & 0.5 & 5.7 & 0.10 & 44 \\
\hline HeLa cells & Chromosomal & Spreading technique & 8,10 & 3.5 & $\sim 3.5$ & 7.0 & 1.0 & 36 \\
\hline
\end{tabular}

* These values were reported to be very variable: "1/3 matrix length up to $20 \mu \mathrm{m}$ ". The values listed here refer to the most frequently given spacer length of $1 / 3$ matrix unit.

$\dagger$ Differing from this figure, Miller and Beatty ${ }^{5}$ mentioned a repeat unit length of $5.5 \mu \mathrm{m}$.

$\ddagger$ If one uses the $5.5 \mu \mathrm{m}$ value for repeat unit length one calculates approximately $40 \%$.

$\S$ These authors, unpublished.

$\mathrm{xx}$ These values are identical with those from chromosomal nucleoli.

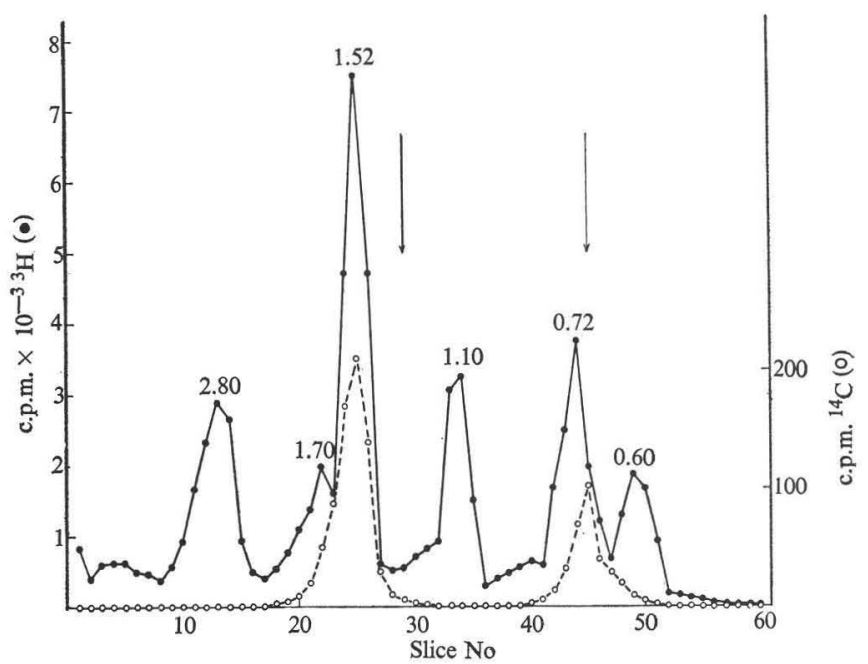

Fig. 4 Separation of labelled RNA from Acheta ovaries on acrylamide-'Agarose' composite gel. Females were injected with $100 \mu \mathrm{Ci}{ }^{3} \mathrm{H}$-uridine each (specific activity $51 \mathrm{Ci} \mathrm{mmol}{ }^{-1}$ ), the ovaries were removed after various times (from $30 \mathrm{~min}-2 \mathrm{~d}$ ) and homogenized at $3^{\circ} \mathrm{C}$ in $0.05 \mathrm{M}$ Tris- $\mathrm{HCl}(p \mathrm{H} 7.6)$ containing $1 \%$ $\mathrm{NaCl}$ and $2 \%(\mathrm{w} / \mathrm{v})$ sodium tri-isopropyl naphthalene sulphonate. Extraction of RNA followed the procedure of Parish and Kirby ${ }^{42}$ as modified by Loening ${ }^{43}$. The precipitated nucleic acids were dissolved in $10 \mathrm{mM}$ Tris- $\mathrm{HCl}(p \mathrm{H} \mathrm{7.2)}$ containing $5 \mathrm{mM} \mathrm{MgCl}_{2}$ and $50 \mu \mathrm{g} \mathrm{ml}^{-1}$ pancreatic DNase (RNase-free, Worthington) for $15 \mathrm{~min}$ at room temperature. The RNA was then precipitated by adding 2 volumes of ethanol at $-20^{\circ}$ C. The pellet was dissolved in E-buffer $(0.02 \mathrm{M}$ Tris- $\mathrm{HCl}$ $p \mathrm{H} 8.0,0.02 \mathrm{M} \mathrm{NaCl}, 2 \mathrm{mM}$ EDTA) containing $0.2 \%$ SDS. After addition of $25 \mu \mathrm{g}{ }^{14} \mathrm{C}$-labelled rRNA obtained from isolated ovarian ribosomes of in vivo labelled X. laevis $^{3}$, the mixture was analysed on slabs of $0.5 \%$ 'Agarose-' $2.25 \%$ acrylamide composite gel at $10 \mathrm{~V} \mathrm{~cm}^{-1}$ (ref. 34). Ribosomal RNA isolated from the microsomal fraction of Tetrahymena pyriformis $(1.32$ and $0.7 \times 10^{6}$ daltons; compare ref. 32 ) was run on the same gel slab in parallel and identified under ultraviolet light. The ge was sliced using parallel razor blades with $1.1 \mathrm{~mm}$ spacing. Radioactivity was measured as described previously ${ }^{3}$. In addition to the $0.72,1.1,1.52,1.70$ and $2.8 \times 10^{6}$ dalton RNAs a defined peak corresponding to an RNA with a molecular weight of about $0.6 \times 10^{6}$ appeared, perhaps representing a cleavage product of one of the processing steps. The RNA pattern was identical when the DNase treatment was omitted. Reference RNAs: ${ }^{14} \mathrm{C}$-labelled $X$. laevis rRNA (O); non-radioactive rRNA ("26S" and "18S") from Tetrahymena pyriformis (indicated by the arrows). of the predominant observed pre-rRNA class of $2.8 \times 10^{6}$ daltons. A third explanation could be that the full transcript of the matrix unit rDNA never exists as a single molecule, but is cleaved while still growing.

Our results show clearly that various types of eukaryotic rDNA have basically a similar overall pattern of arrangement in that region coding for pre-rRNA alternate with spacer segments, which do not code for the rRNA precursor (Table 1). The present data are not compatible with the concept of Perry et al. ${ }^{33}$ who thought that the sum of matrix unit length and "spacer" length would be constant during eukaryotic evolution. The data available at the moment (Table 1) show that in this respect the situation in the amplified rDNA of Acheta is somewhat different, not only from the amplified rDNA of amphibia but also from the chromosomal nucleoli in Chironomus salivary glands ${ }^{41}$ and rat liver. Acheta has the longest repeat unit so far demonstrated. Our results also show that the repeat unit of the rDNA from different species does not have a constant length but varies widely. We propose that the relative lengths of the two segments in rDNA have to be defined for each organism or taxonomic group. Another hypothetical alternative that chromosomal and extrachromosomal rDNA might have different patterns seems to be contradicted by the measurements of Dawid et al. ${ }^{11}$ and Wensink and Brown ${ }^{12}$.

We thank Miss Marianne Winter for technical assistance, Drs H. Falk and R. R. C. Kay for discussing and correcting the manuscript, and Dr Lima-de-Faria for discussions.

\section{Michael F. TrendelenburG ULRICH SCHEER} WERnER W. FRANKE

Division of Membrane Biology and Biochemistry,

Institute of Experimental Pathology,

German Cancer Research Center, D-69 Heidelberg, and Department of Cell Biology,

Institute of Biology II,

University of Freiburg, D-78 Freiburg i. Br.

Received May 25; revised August 6, 1973.

${ }^{1}$ Miller, O. L., and Beatty, B. R., Genetics Suppl., 61, 133 (1969).

2 Reeder, R. H., and Brown, D. D., J. molec. Biol., 51, 361 (1970).

3 Scheer, U., Trendelenburg, M. F., and Franke, W. W., Expl. Cell Res. (in the press)

4 Miller, O. L., and Beatty, B. R., Science, N.Y., 164, 955 (1969).

5 Miller, O. L., and Beatty, B. R., J. cell Physiol., 74, Suppl. 1, 225 (1969). 
${ }^{6}$ Miller, O. L., and Beatty, B. R., in Handbook of Molecular Cytology (edit. by Lima-de-Faria, A.), 305 (North-Holland, Amsterdam, 1969).

7 Miller, O. L., Beatty, B. R., Hamkalo, B. R., and Thomas, C. A., Cold Spring Harbor Symp. quant. Biol., 35, 505 (1970).

8 Miller, O. L., and Bakken, A. H., Acta endocr., Suppl., 168, 155 (1972).

9 Miller, O. L., and Hamkalo, B. A., Int. Rev. Cytol., 33, 1 (1972).

10 Miller, O. L., Scient. Am., 228, 34 (1973).

11 Dawid, I. B., Brown, D. D., and Reeder, R. H., J. molec. Biol., 51, 341 (1970).

12 Wensink, P. C., and Brown, D. D., J. molec. Biol., 60, 235 (1971).

13 Brown, D. D., Wensink, P. C., and Jordan, E., J. molec. Biol., 63, 57 (1972).

14 Lima-de-Faria, A., Chromosoma, 13, 47 (1962)

15 Gall, J. G., MacGregor, H. C., and Kidston, M. E., Chromosoma, 26, 169 (1969).

16 Cave, M. D., and Allen, E. R., Expl Cell Res., 58, 201 (1969).

17 Hansen-Delkeskamp, E., Z. Naturforsch., 24b, 1331 (1969).

18 Lima-de-Faria, A., Birnstiel, M., and Jaworska, H., Genetics, Suppl., 61, 145 (1969).

19 Lima-de-Faria, A., Gustaffson, T., and Jaworska, H., Hereditas, 73, 119 (1973)

20 Lima-de-Faria, A., Nillson, B., Cave, D., Puga, A., and Jaworska, H., Chromosoma, 25, 1 (1968).

21 Kunz, W., Chromosoma, 26, 41 (1969).

22 Allen, E. R., and Cave, D. M., Z. Zellforsch., 101, 63 (1969).

23 Cave, M. D., and Allen, E. R., Z. Zellforsch., 120, 309 (1971).

24 Hansen-Delkeskamp, E., Wilhelm Roux' Arch., 170, 344 (1972).

25 Favard-Séréno, C., J. Microscopie, 7, 205 (1968).
26 Jaworska, H., and Lima-de-Faria, A., Chromosoma, 28, 309 (1969).

27 Granboulan, N., and Scherrer, K., Eur. J. Biochem., 9, 1 (1969).

28 Verma, I. M., Edelman, M., Herzberg, M., and Littauer, U. Z., J. molec. Biol., 52, 137 (1970).

${ }^{29}$ Robberson, D., Aloni, Y., Attardi, G., and Davidson, N., J. molec. Biol., 60, 473 (1971).

30 Nanninga, N., Meyer, M., Sloof, P., and Reijnders, L., J. molec. Biol., 72, 807 (1972).

31 Rogers, M. E., and Klein, G., Biochem. J., 130, 281 (1972).

32 Loening, U. E., J. molec. Biol., 38, 355 (1968).

33 Perry, R. P., Cheng, T.-Y., Freed, J. J., Greenberg, J. R., Kelley, D. E., and Tartof, K. D., Proc. natn. Acad. Sci. U.S.A., 65, 609 (1970).

${ }^{34}$ Ringborg, U., Daneholt, B., Edström, J.-E., Egyházi, E., and Lambert, B., J. molec. Biol., 51, 327 (1970).

35 Rubinstein, L., and Clever, U., Biochim. biophys. Acta, 246, 517 (1971).

36 Dalgarno, L., Hosking, D. M., and Shen, C. H., Eur. J. Biochem., 24, 498 (1972).

${ }^{37}$ Pero, R., Lima-de-Faria, A., Ståhle, U., Granström, H., and Ghatnekar, R., Hereditas (in the press).

38 Caston, D. J., and Jones, P. H., J. molec. Biol., 69, 19 (1972).

39 Hidvégi, E. J., Prestayko, A. W., and Busch, H., Physiol. Chem. Phys., 3, 17 (1971).

40 Grummt, I., and Lindigkeit, R., Eur. J. Biochem. (in the press).

41 Derksen, J., Trendelenburg, M. F., Scheer, U., and Franke, W. W., Expl Cell Res. (in the press).

42 Parish, J. H., and Kirby, K. S., Biochim. biophys. Acta, 129, 554 (1966).

${ }^{43}$ Loening, U. E., Biochem. J., 102, 251 (1967). 